\title{
MASSIVE INTRACRANIAL IMMATURE TERATOMA
}

\author{
REPORT OF A CASE WITH POLYHIDRAMNIOS \\ AND INTENSE PELVIC PAIN
}

\author{
FERNANDO A. SOARES*, SANDRA ELISABETH FISCHER * \\ MARLENE ANTONIA DOS REIS***, EDSON GARCIA SOARES*
}

\begin{abstract}
A case of massive intracranial immature teratoma in a female stillborn is reported. She was the product of the second pregnancy of a 25 -year-old healthy woman. The pregnancy was unremarkable until the 25th week of gestation when the mother noticed a rapid enlargement of her abdomen and intense pelvic pain. Because of the pain, a cesarean section was indicated, and a stillborn weighing $2750 \mathrm{~g}$ with macrocephaly was delivered. The cranial contents weighed $1350 \mathrm{~g}$ and showed a huge tumoral mass with only a rim of normal brain. A histologic diagnosis of immature teratoma was made. Massive intracranial teratomas are rare tumors and their occurrence in intrauterine life is even rarer. Their histogenesis is unknown, and there is no explanation for their continuous growth during embryogenesis. A prenatal diagnosis of this rare condition can be made by ultrasound, computed tomography, or magnetic resonance imaging.
\end{abstract}

KEY WORDS: immature teratoma, intracranial congenital tumor.

Teratoma imaturo gigante intracraniano: relato de caso com poli-hidrâmnio e dor pélvica intensa

RESUMO - Um caso de teratoma imaturo gigante do sistema nervoso central em um natimorto é relatado. Durante a gravidez, a mãe desenvol veu poli-hidrâmnio abrupto na $25^{\circ}$ semana de gestação e dor pélvica intensa, que levou a indicação de cesárea. O natimorto pesava $2750 \mathrm{~g}$, apresentava macrocefalia evidente e o conteúdo craniano pesou $1350 \mathrm{~g}$. Este era representado por tecido tumoral em sua maioria e apenas uma pequena rima de tecido encefálico normal. A histologia mostrou tratar-se de um teratoma imaturo. Teratomas intracranianos gigantes congênitos são neoplasias raras, de histogênese incerta e não há explicação para o crescimento contínuo e rápido durante a vida intra-uterina. $O$ diagnóstico pré-natal pode ser realizado por ultra-sonografia, tomografia computadorizada ou ressonância magnética.

PALAVRAS-CHAVE: teratoma congênito, tumor intracraniano congênito.

Intracranial congenital teratomas which develop during intrauterine life are very rare. They are interesting because of their obscure origin, and because they are characterized by continuous growth. Their incidence has been estimated at $0.5 \%$ of all intracranial tumors, and only $2 \%$ of subjects are children ${ }^{19}$. The majority of these tumors are large, many of them presenting with macrocephaly or hydrocephaly. The baby is usually a stillbom.

We report here a massive immature intracranial teratoma that replaced most of the brain of a stillborn female fetus.

Department of Pathology, Faculty of Medicine of Ribeirāo Preto, University of Sāo Paulo: *Assistant Professor, **Post Graduation Student,*** former Resident. Aceite: 11-dezembro-1995.

Dr. Fernando A. Soares - Department of Pathology, Faculty of Medicine of Ribeirăo Preto -14049-900 Ribeirāo Preto SP - Brazil . Fax +55 (0)16. 633 1068. Intemet address: fasoares@ fmrp.usp.br 


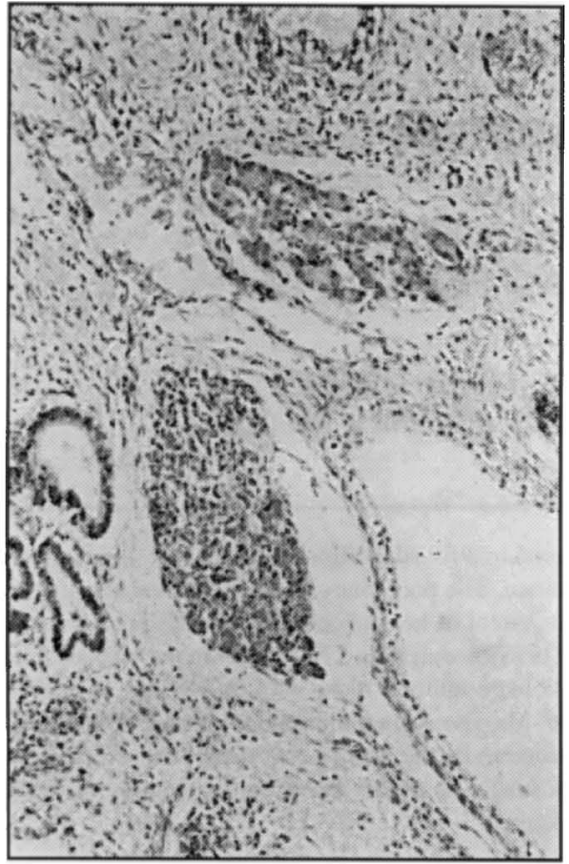

Fig l. Low power photomicrograph showing liver and respiratory epithelium. $H \& E, X 40$

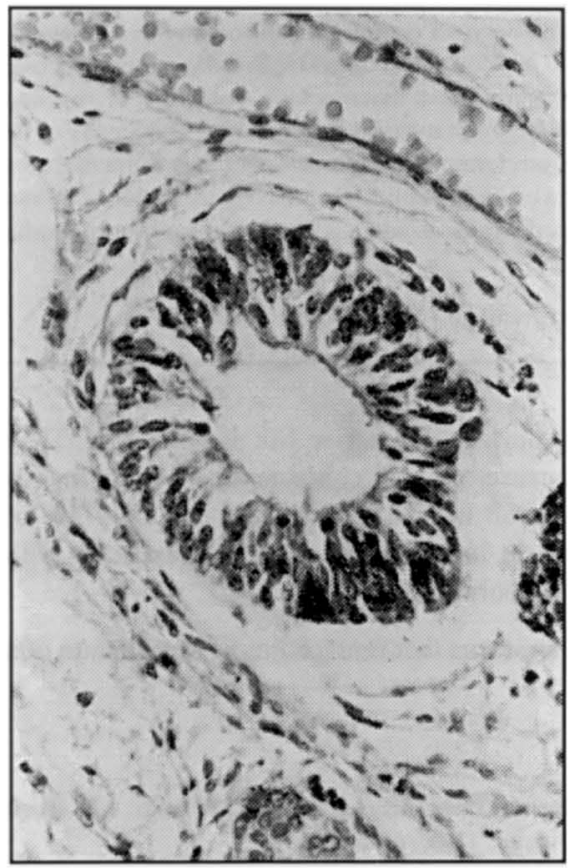

Fig 3. Photomicrograph showing an immature neural tissue. $H \& E, X 250$

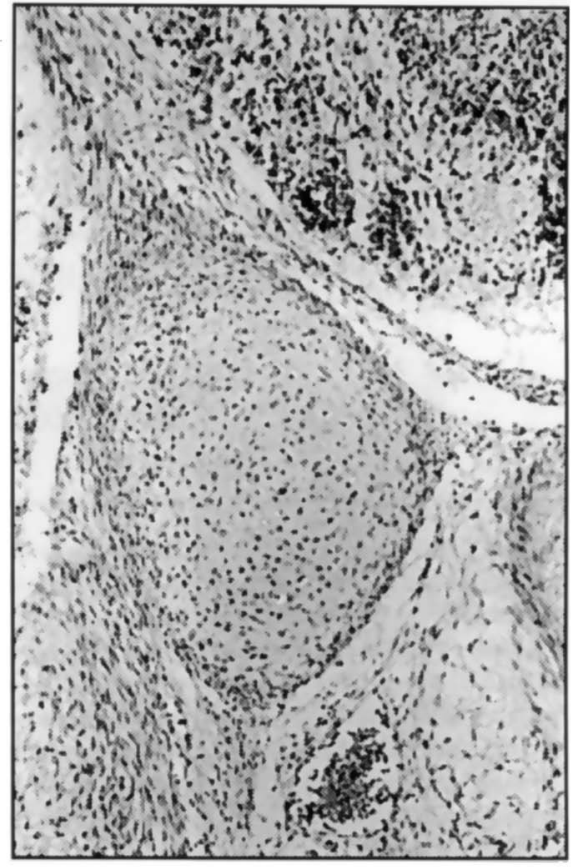

Fig 2. A cartilage tissue island in one of microscopic sections. $H \& E, X 100$

\section{CASE REPORT}

A female stillborn was the product of the second pregnancy of a 25-year-old woman. The mother was otherwise in good health and the serological tests for syphilis and toxoplasmosis were non-reactive. The farnily history was unremarkable. The first child was born 5 years previously, following a normal pregnancy and delivery. The current pregnancy was uneventful until the 25 th week when the patient noticed rapid enlargement of her abdomen. The ultrasound investigation revealed polyhidramnios and fetal macrocephaly. A diagnosis of hydrocephaly with possible central nervous system malformations was suspected. At the 28th week of gestation, the mother complained of intense and persistent pelvic pain. An amniocentesis was performed, and $2000 \mathrm{ml}$ of amniotic fluid containing meconium was withdrawn. A diagnosis of intrauterine death was made, and the stillborn fetus was delivered by cesarean section because of the intense pelvic pain.

At autopsy, the fetus weighed $2750 \mathrm{~g}$. There was obvious macrocephaly (the head circumference was $39 \mathrm{~cm}$ ) with thin cranial bones. The fontanels were enlarged. The cranial contents weighed $1350 \mathrm{~g}$ ( $49 \%$ of the total body weight), and a huge tumoral mass with a rim of normal brain tissue was observed. Grossly, the tumor was grayish and fleshy, with areas of hemorrhage 
and little cysts filled with mucinous fluid. Histologically, it was composed of a variety of tissues derived from all germinal layers. Neural tissues, liver (Fig 1), respiratory epithelium (Fig 1), cartilage (Fig 2), bone, mucosal glands, and cysts with endodermal linings were identified. Solid sheets of immature neural tissue with abortive medullary channels were frequently observed (Fig 3). Necrotic tissue was extensive. Except for the immature teratoma, no other congenital anomalies were observed, and no other lesions were found.

\section{DISCUSSION}

Intracranial immature teratomas are rare neoplasms accounting for $0.4 \%$ of all encephalic tumors in Brazil ${ }^{16}$, and their occurrence during intrauterine life is even rarer, although they are the single most common intracranial congenital tumor ${ }^{20}$. Haddad et al. reported a series of 22 congenital brain tumors in which 2 of them were malignant teratomas ${ }^{10}$. In another series of 45 cases, immature teratomas and primitive neuroectodermal tumors were the most common tumors with 12 cases each ${ }^{3}$. During infancy, the sacrococcygeal and mediastinal areas, and the gonads are the most common sites of occurrence. In a review of 91 cases of teratomas in infancy and childhood, Berry et al described only 3 cases of intracranial teratomas, and just one was massive and with immature elements ${ }^{2}$. In another series, Carney et al. reported 58 cases of teratomas in children, 7 of them intracranial, but none was observed before 2 years of age 4 .

Most of our knowledge about intracranial massive teratoma have been established by the report of anecdotal cases ${ }^{13}$. Teratomas generally arise in the midline position. The most common sites are pineal, pituitary fossa, and the third ventricle ${ }^{25}$. However, in the case of massive teratomas the site of origin is uncertain. The massive intracranial teratomas usually replace the entire brain ${ }^{5,18}$, although remnants of non-neoplastic tissue can be observed, such as in the present case ${ }^{17.18}$. Extracranial extension to the orbit ${ }^{9,13,14}$, the pharynx, and the neck ${ }^{1,18}$ has been reported.

Polyhidramnios is a common sign in cases of massive intracranial teratomas ${ }^{18.22}$. Polyhidramnios might have been caused by nearly complete replacement of the brain parenchyma with destruction of the brainstem, or diabetes insipidus from hypothalamic destruction could have been responsible for the polyhidramnios ${ }^{18}$. Other manifestations such as pelvic pain, edema, hepatomegaly, extramedullary hematopoiesis, and hydropic placenta have been reported ${ }^{22}$. Massive hydrocephalus and facial deformities can be caused by small tumors, usually localized near to the ventricles ${ }^{12}$.

There is no explanation as yet for the massive growth during the embryonic phase. Two main theories have been proposed to explain the growth phenomenon. One of them is related to the time of evolution, i.e., the neoplasm originates closer to the time of conception and grows for several months before birth. The other hypothesis is that the fetal period offers a better environment for growth of the immature elements. An argument for the latter theory is that the majority of these neoplasms are immature. The tumor is always made up of a large amount of primitive neural elements, including small undifferentiated neuroepithelial cells and immature glial fibers ${ }^{21}$. Congenital intracranial teratoma is not always massive however, and small tumors have been reported ${ }^{13}$. The nature of factors that determine the growth rate, and by consequence, the tumor size, remains speculative.

Formerly, the diagnosis of congenital intracranial teratomas was usually made at autopsy. More recently, diagnosis has been achieved by ultrasound and computerized tomography ${ }^{3,4,15.17}$. The distinction between teratoma, other cystic lesions, and hydrocephaly is not always easy, though it is essential in terms of prognosis. The features revealed by ultrasound and CT include polyhidramnios and macrocrania in addition to alterations of the anatomical shape of the brain with or without calcifications and cysts ${ }^{3}$. The differential diagnosis with more rare lesions, such as porencephaly, hydrancephaly, and holoprosencephaly must be included although the alterations of intracranial anatomy are more consistent with the diagnosis of tumors ${ }^{17}$. The combined use of ultrasound, magnetic resonance imaging, and computerized tomography improves the diagnostic accuracy before delivering ${ }^{23}$. The outcome of those tumors has been very poor, but neonates with intracranial teratoma have survived surgery and developed normally therafter ${ }^{8,24,26}$. The approach in cases of massive 
intracranial teratoma is obviously more complex due to the extension of the tumor. Size and favorable location is the most important determinant in the outcome regardless of the histologic classification as mature or immature ${ }^{\prime \prime}$. Dolkart et al. reported a case of massive tumor in which the neonate survived without treatment ${ }^{7}$. Responses with combined chemotherapy have been observed ${ }^{6.23}$. Early diagnosis based that new diagnostic techniques may improve prognosis.

\section{REFERENCES}

1. Arai $\mathrm{H}$, Sato K, Kadota $\mathrm{Y}$, lto M, Ishimoto K, Yanai A. Skull base reconstruction in cases of intracranial teratoma extending in to the extracranial structures. Surg Neurol 1992;38:383-390.

2. Berry CL, Keeling J, Hilton C. Teratomata in infancy and childhood: a review of 91 cases. J Pathol 1969;98:241-252.

3. Buetow PC, Smimiotopoulos JG, Done S. Congenital brain tumors: a review of 45 cases. AJR 1990;155:587-593.

4. Carney JA, Thompson DP, Johnson CL, Lynn HB. Teratomas in children: clinical and pathologic aspects. J Pediatr Surg 1972;7:271-282.

5. Char G, Persaud V, Lyons B. Massive congenital intracranial teratoma: report of a case in a hydrocephalic foetus. W Ind Med J 1985;34:274-277.

6. Dearnaley DP, A'Hern RP. Whittaker S, Bloom HJ. Pineal and CNS germ cell tumors: Royal Marsden Hospital experience 1962-1987. Int J Radiat Oncol Biol Phys 1990;773-781.

7. Dolkart LA, Balcom RJ, Eisinger G. Intracranial teratoma: prolonged neonatal survival after prenatal diagnosis. Am J Obstet Gynecol 1990;162:768-769.

8. Ferreira J, Eviatar L, Schneider S. Grossman R. Prenatal diagnosis of intracranial teratoma: prolonged survival after resection of a malignant teratoma diagnosed prenatally by ultrasound. A case report and literature review. Pediatr Neurosurg 1993;19:84-88.

9. Garden JW, McManis J. Congenital orbital-intracranial teratoma with subsequent malignancy: case report. Br J Ophthalmol 1986;111-113.

10. Hahhad SF, Menezes AH, Bell WE, Godersky JC, Afifi AK, Bale JF. Brain tumors occurring before 1 year of age: a retrospective reviews of 22 cases in an 11 year period (1977-1987). Neurosurgery 1991;29:8-13.

11. Hunt SJ, Johnson PC, Coons SW, Pittman HW. Surg Neurol 1990;34:336-342.

12. Kuller JA, Laifer SA, Martin JG, MacPherson TA, Mitre B, Hill LM. Unusual presentation of fetal teratoma. J Perinatol 1991;11:294-296.

13. Nanda A, Schut L, Sutton LN. Congenital forms of intracranial teratoma. Childs Nerv Syst 1991;7:112-114.

14. Neiger R, Sacks LM. Massive orbital and intracranial teratoma in the newborn: a case report. J Med Assoc Ga 1989;78:811-813.

15. Oi S, Tamaki N, Kondo T, Nakamura H, Kudo H, Suzuki H, Sasaki M, Matsumoto S, Ueda Y, Katayama K. Massive congenital intracranial teratoma diagnosed in utero. Child Nerv Syst 1990;6:459-461.

16. Registro Nacional de Patologia Tumoral. Diagnósticos de câncer no Brasil - 1981/85. Brasília: Ministério da Saúde, 1991.

17. Richards SR. Ultrasonic diagnosis of intracranial teratoma in utero: a case report and literature review. J Reprod Med 1987;12:73-75.

18. Rostad S, DeMasters BKK, Manchester DK. Two massive congenital intracranial immature teratomas with neck extension. Teratology 1985;32:163-169.

19. Russel DS, Rubinstein LJ. Pathology of tumors of the central nervous system. Ed 5. Baltimore: Williams \& Wilkins; 1989; 681 .

20. Sabet LM. Congenital glioblastoma multiform associated with congestive heart failure. Arch Pathol Lab Med 1982;106-31-33.

21. Saiga T, Osasa H, Hatayama H, Miyamoto T, Ono H, Mikami T. The origin of extragonadal teratoma: case report of an immature teratoma occurring in a prenatal brain. Pediatr Pathol 1991;11:759-770

22. Sherer DM, Abramowicz JS, Eggers PC, Metlay LA, Sinkin RA, Woods JR Jr. Prenatal ultrasonographic diagnosis of intracranial teratoma and massive craniomegaly with associated high-output cardiac failure. Am J Obstet Gynecol 1993;168:97-99.

23. Takakura K. Intracranial germ cell tumors. Clin Neurosurg 1985;32:429-444.

24. Ulreich S, Hanieh A, Furness ME. Positive outcome of fetal intracranial teratoma. Ultrasound Med 1993;12:163-165.

25. Wakai S, Arai T, Nagai M. Congenital brain tumors. Surg Neurol 1984;21:597-609.

26. Whittle IR, Simpson DA. Surgical treatment of neonatal intracranial teratoma. Surg Neurol 1981;15:268-273. 